\title{
Peningkatan Kemampuan Berhitung 1-20 Melalui Penggunaan Media Corong Berhitung pada Siswa Kelompok B1 Taman Kanak-Kanak Muslimat Wonocolo Surabaya
}

\author{
Fajar Karuniawati ${ }^{1}$, Mukhoiyaroh $^{2}$
}

Received: 2305 2019 / Accepted: 2305 2019 / Published online: 15062019 (C) 2019 Early Chilhood Islamic Education Study Program

\begin{abstract}
This research is backgrounded by the low ability in counting 1-20 related to calculation and diminution. It is proven by the result of doing the enrichment exercises which was done by 20 students in a class but only 5 students who got BHS score (Berkembang Sesuai Harapan) in the indicator of mentioning calculation result. Therefore, the objective of this research is to know the use of funnel calculation media in order to increase the ability in counting 1-20 for the students of Kindergarten Muslimat Wonocolo Surabaya, and to know the raising ability in counting 1-20 by using the funnel calculation media related to calculation and diminution. The research design which is used in this research is action research by using Kurt Lewin model. It consists of pre-cycle, cycle I, cycle II and reflection. The participant of this research is 20 students of B-1 group at TK Muslimat Wonocolo Surabaya. The action research of Lewin Kurt model consists of 4 stages; planning, implementation, observation and reflection. The results of this research are: 1) The use of funnel calculation goes well in cycle I. It can be seen in the activity of the students which enthusiastic in using funnel calculation media. Besides, the observation result of the teachers and students get the score in the percentage of 63,09\%. It also can be seen from the activity of the teachers and students which rises by getting the score of 79,76\% with the increase in 6,65.2) There is an increasing of the ability in calculating 1-20 which is proven by the raising of the score after using funnel calculating media in cycle I in amount of $63,74 \%$ and the cycle II in amount of $76,87 \%$ by the increasing in the percentage of 13,13 .
\end{abstract}

Keywords: The Ability of counting, corong berhitung (Funnel Caclculation).

Abstrak: Penelitian ini dilatarbelakangi oleh rendahnya kemampuan berhitung 120 terkait penjumlahan dan pengurangan. Hal ini dibuktikan dengan hasil mengerjakan latihan pengayaan,dari 20 siswa dalam satu kelas hanya 5 siswa yang mendapat skor BSH (Berkembang Sesuai Harapan) pada indikator menyebutkan hasil penjumlahan, sedangkan 3 siswa dengan skor $\mathrm{BSH}$ (Berkembang Sesuai Harapan) pada indikator pengurangan. Oleh karena itu, tujuan dari penelitian ini adalah untuk mengetahui penggunaan media corong berhitung dalam rangka meningkatkan kemampuan berhitung 1-20 pada siswa TK Muslimat Wonocolo Surabaya, serta untuk mengetahui peningkatan kemampuan berhitung 1-20 dengan menggunakan media corong terkait penjumlahan dan pengurangan. Metode yang digunakan dalam penelitian ini adalah Penelitian Tindakan Kelas (PTK) dengan model Kurt Lewin. Terdiri dari pra siklus, siklus I, dan siklus II, dan refleksi. Subyek penelitian ini adalah siswa kelompok B1 TK

\footnotetext{
${ }^{1} \mathrm{~KB} / \mathrm{TK}$ Dian Ceria Surabaya

${ }^{2}$ UIN Sunan Ampel Surabaya
} 
Muslimat Wonocolo Surabaya yang terdiri 20 siswa. Penelitian Tindakan Kelas model Kurt Lewin terdiri dari 4 tahapan, yaitu perencanaan, pelaksanaan, pengamatan, dan refleksi. Teknik pengumpulan data yang digunakan yaitu: wawancara, dokumentasi, dan tes pengayaan. Hasil penelitian ini adalah sebagai berikut: 1) Penggunaan media corong berhitung berjalan dengan baik pada siklus I. Hal ini dilihat pada aktivitas siswa yang antusias dalam penggunaan media corong berhitung, selain itu juga pada hasil observasi guru dan siswa yang mendapat skor dengan persentase $63,09 \%$. Selain itu dapat dilihat dari aktivitas guru dan siswa yang meningkat dengan perolehan skor $79,76 \%$, dengan kenaikan $6,65.2)$ Adanya peningkatan kemampuan berhitung 1-20 yang dibuktikan dengan peningkatan nilai setelah menggunakan media corong berhitung pada siklus I sebesar $63,74 \%$ dan pada siklus 2 sebesar $76,87 \%$ dengan kenaikan perolehan persentase sebesar 13,13.

Kata Kunci: Kemampuan Berhitung 1-20, Corong Berhitung

\section{PENDAHULUAN}

Berhitung permulaan merupakan perkembangan yang masih dasar atau awal tentang aspek kognitif yang masuk ke dalam ilmu matematika sederhana. Kemampuan berhitung pada anak usia dini adalah suatu bentuk potensi pada setiap individu sejak lahir yang dilakukan secara terus menerus sehingga menjadi kebiasaan dan latihan untuk dapat melakukan kegiatan berhitung (Ahmad Susanto, 2011: 97). Menurut Susanto, menjelaskan tentang pengertian kemampuan berhitung adalah kemampuan yang dimiliki oleh setiap anak untuk mampu dalam melakukan kegiatan berhitung yang dimulai dari lingkungan terdekat anak, sehingga kemampuan yang dimiliki anak tersebut mampu berlanjut ke tahap pengertian mengenai jumlah, terkait tentang penjumlahan dan pengurangan sederhana yaitu bilangan 1-20 (Ahmad Susanto, 2011: 56).

Sesuai dengan penjelasan di atas dapat dikatakan bahwa kemampuan berhitung pada anak usia dini termasuk pada aspek kognitif tentang Matematika yang berkaitan dengan pengenalan konsep suatu bilangan dan lambang bilangan serta penjumlahan dan pengurangan sederhana. Dengan demikian, kemampuan untuk melakukan kegiatan berhitung yang dimulai dari anak mampu mengenal lambang bilangan merupakan salah satu tahapan dalam berhitung anak usia dini dari anak mampu mengenal lambang bilangan merupakan salah satu tahapan dalam berhitung anak usia dini.

Pembelajaran berhitung berkaitan dengan penjumlahan dan pengurangan sederhana juga dijelaskan oleh Sri Ningsih dalam bukunya Pembelajaran Matematika Terpadu untuk Anak Usia Dini, yang menjelaskan bahwa kegiatan berhitung sudah banyak diajarkan pada anak usia dini baik dari jalur formal maupun non formal (Sriningsih, 2008: 123). Sesuai dengan pendapat Sri Ningsih diatas, maka perlu adanya suatu kegiatan yang dirancang guna untuk melatih kemampuan berhitung agar anak mampu melakukan kegiatan berhitung sederhana. Tujuan dari pembelajaran berhitung adalah untuk meningkatkan kemampuan yang dimiliki yang bekerja pada jenjang berikutnya dan memungkinkan anak untuk menekankan pada tahap pemecahan masalah

Sesuai dengan penjelasan dari tujuan pembelajaran berhitung, sehingga dengan kata lain kemampuan berhitung pada anak usia dini yang dipelajari dalam hal ini adalah mengacu pada indikator kompetensi yang ingin dicapai. Terdapat empat indikator 
kemampuan berhitung kelompok B (usia 5-6 tahun) yang ada pada Taman Kanak-kanak Muslimat Wonocolo Surabaya, yaitu membilang/menyebutkan bilangan 1-20, menghubungkan lambang bilangan dengan benda-benda sampai 20, menyebutkan hasil penjumlahan 1-20, dan menyebutkan hasil pengurangan 1-20. Namun, karena saat observasi awal, ditemukan kemampuan anak dengan menyebutkan bilangan 1-20 dan menghubungkan lambang bilangan dengan benda-benda 1-20 di nilai sudah maksimal. Sedangkan berbeda dengan indikator terkait penjumlahan dan pengurangan yang masih rendah. Dalam hal ini penulis, ingin memfokuskan pada kemampuan berhitung dalam pengurangan dan penjumlahan 1-20.

Melihat pada kondisi saat ini, banyak tuntutan orang tua yang menginginkan anaknya untuk mampu dalam hal penjumlahan dan pengurangan, atau berkaitan dengan konsep berhitung. Sehingga lembaga TK mengajarkan penjumlahan dan pengurangan secara sederhana dan bukan merupakan hal yang menjadikan merusak otak anak. Terlebih, apabila anak usia dini berada pada tahap berhitung permulaan diajarkan dengan cara menghitung benda-benda di sekitar lingkungan terdekat yang memungkinkan anak terbiasa dapat memahami tentang konsep jumlah dan juga bilangan. Selain itu, kematangan mengenai konsep berhitung akan mengena kepada anak apabila hal tersebut selalu dilakukan dengan konsisten dan kondusif. Dalam hal ini, perlu adanya bentuk pemanfaatan media yang menarik agar anak tertarik untuk belajar tentang berhitung yang akan berhubungan pada jenjang sekolah dasar.

Persoalan terkait kemampuan berhitung yang penulis lakukan ketika observasi awal adalah kurangnya motivasi dan juga penggunaan media yang dapat meningkatkan anak dalam penguasaan konsep penjumlahan dan pengurangan. Ditunjukkan pada saat guru memberikan penjelasan terkait menggabungkan dua buah benda dengan jumlah yang berbeda (penjumlahan) dengan menggunakan jari, ini satu ini dua, dan seterusnya. Kemudian melakukan kegiatan latihan pengerjaan soal yang dikerjakan di buku tulis.

Data yang diperoleh ketika observasi awal ditunjukkan berupa pengamatan peneliti dimana guru memberikan materi penjumlahan dan pengurangan yang sedemikian rupa secara klasikal dengan secara langsung. Tampak penggunaan media hanya papan tulis dan lembar kerja siswa. Berkaitan dengan observasi yang ada diperoleh data hasil pretest yaitu, dari jumlah siswa secara keseluruhan kelompok B1 sebanyak 20 siswa, hanya 7 siswa yang sudah mampu melakukan kemampuan berhitung terkait penjumlahan dengan dibuktikan 2 siswa atau 10\% mendapat skor BB (Belum Berkembang), 12 siswa atau 60\% MB (Mulai Berkembang), 5 siswa atau 25\% mendapat skor BSH (Berkembang Sesuai Harapan), dan 1 siswa atau 5\% mendapat skor BSB (Berkembang Sangat Baik). Sedangkan dalam melakukan kegiatan pengurangan hanya 5 siswa yang mampu melakukan, sedangkan sisanya masih perlu bimbingan dengan dibuktikan 5 siswa atau $25 \%$ mendapat skor belum berkembang, 12 siswa atau $60 \%$ mendapat skor mulai berkembang, 3 siswa atau 15\% mendapat skor Berkembang sesuai harapan.

Berdasarkan wawancara dengan guru kelas Kelompok B1 yaitu Ibu YN pada tanggal 24 Februari 2018, di dapat informasi bahwa anak sering bosan, dan bergurau sendiri, dan guru hanya menggunakan papan tulis dalam proses pembelajaran, tetapi guru juga tidak memiliki pilihan media pembelajaran terkait berhitung yang digunakan, sehingga masih menggunakan media yang sama, yaitu jari tangan dan pengerjaan lembar kegiatan siswa. Oleh sebab itu, perlu adanya cara terkait kemampuan berhitung dengan menggunakan media yang berbeda, agar siswa aktif dan tidak bosan dalam mengikuti kegiatan belajar. 
Apabila anak usia dini secara terus menerus dibimbing dan diberikan arahan terkait kemampuan berhitung yang dimiliki melalui cara sederhana seperti dimulai dari mengenalkan konsep lambang bilangan kemudian mengarah pada mengurutkan lambang bilangan dengan kegiatan yang menyenangkan, maka otak kanan anak akan terlatih untuk terus berkembang, sehingga anak dapat menguasai dan bahkan menyenangi kegiatan berhitung tersebut. Mengarah pada alternatif pemecahan masalah yang ada pada kelompok B1 TK Muslimat Wonocolo Surabaya terkait kurangnya peningkatan kemampuan berhitung 1-20 penjumlahan dan pengurangan maka menuntut guru untuk lebih kreatif dalam menciptakan media yang tidak terkesan monoton, menarik, mudah di dapat dan juga murah.

Media pembelajaran adalah sarana atau alat yang digunakan untuk menyalurkan, menyampaikan informasi atau materi pelajaran dari pemberi pesan kepada penerima pesan (Mukhtar Latif, 2013: 151). Sedangkan menurut Arif S Sadiman, mengatakan bahwa jenis-jenis media pembelajaran terdiri dari media grafis yaitu media visual yang melibatkan indera penglihatan, media audio, dan media proyeksi diam (Aris S Sadiman, 2006: 19). Dengan demikian, corong berhitung tergolong jenis media grafis. Sedangkan tujuan suatu media pembelajaran dibuat, yaitu agar proses pembelajaran menjadi lebih mudah, efektif, dan efisien sesuai karakter peserta didik sehingga pesan atau materi belajar akan tersampaikan dengan baik. Selain itu, tujuan penggunaan media pembelajaran menurut Sujiono adalah untuk merangsang anak melakukan berbagai kegiatan, pikiran, perasaan, perhatian dan minat, bereskperimen, alat bantu, serta pada mengembangkan imajinasi (Sujiono, Yuliani dkk, 2004: 8).

\section{METODE}

Pada Jenis penelitian ini menggunakan jenis penelitian tindakan kelas (PTK) atau dalam Bahasa Inggris Classroom Action Research, yaitu penelitian yang dilakukan pada sebuah kelas untuk mengetahui akibat tindakan yang diterapkan pada suatu subyek penelitian di kelas tersebut (Suharsimi Arikunto, 2006: 93). Metode penelitian yang digunakan dalam penelitian tindakan kelas ini adalah model Kurt Lewin, menurut Kurt Lewin model yang dijadikan acuan pokok dasar selama ini dari berbagai model action research, terutama classroom action research. Model ini terdiri dari empat komponen. Yaitu tahap perencanaan (planning), tahap pelaksanaan (acting), tahap pengamatan atau observasi (observing), dan tahap refleksi (reflecting) (Hamzah B Uno, 2012: 87).

A. Setting Penelitian dan Karakteristik Subyek Penelitian

1. Setting Penelitian

a. Tempat Penelitian : TK Muslimat Wonocolo Surabaya

b. Waktu Penelitian : Semester genap tahun ajaran 2017-2018

2. Subyek Penelitian

Subyek dalam penelitian ini adalah siswa-siswi kelompok B1 TK

Muslimat Wonocolo Surabaya yang berjumlah 20 siwa dalam satu kelas.

B. Analisis Penelitian

1. Nilai observasi guru dan siswa

2. Nilai rata-rata 


\section{HASIL PENELITIAN DAN ANALISIS}

Peningkatan kemampuan berhitung siswa kelompok B1 dilakukan dengan menggunakan lembar kerja siswa yang diberikan pada hari ketiga siklus I dan siklus II, alasan pemberian lembar kerja siswa pada siklus I dan siklus II adalah untuk meminimalisir kebosanan siswa dalam mengerjakan lembar kerja. Dengan begitu, siswa lebih semangat mengerjakan dan fokus pada hari ketiga siklus I dan siklus II.

Adapun kegiatan yang dilakukan pada hari pertama dan kedua baik dalam siklus I dan siklus II adalah untuk mengetahui bagaimana aktivitas yang dilakukan siswa dan guru dalam upaya peningkatan kemampuan berhitung. Meski demikian, siswa tetap diberikan kartu soal sebagai bahan pengajaran, bukan berarti tidak mendapatkan tugas. Hanya saja tidak untuk menuliskan pada lembar kerja, bentuk kegiatan yang dilakukan adalah secara langsung atau unjuk kerja terhadap penggunaan media corong berhitung.

Dari 20 siswa dalam satu kelas pada indikator menyebutkan hasil penjumlahan 120 diketahui bahwa, 7 siswa mendapat skor BSB (45\%), 11 siswa mendapat skor BSH (55\%), dan 2 siswa mendapat skor MB (10\%). Sedangkan pada indikator menyebutkan hasil pengurangan 4 siswa mendapat skor BSB (20\%), 12 siswa mendapat skor BSH $(60 \%), 4$ siswa mendapat skor MB (20\%).

\section{PEMBAHASAN}

TK Muslimat Wonocolo Surabaya adalah salah satu Taman kanak-kanak yang berlokasi di daerah Jemur Wonosari yang berada dibawah Yayasan Ma'arif NU Wonocolo. Pembelajaran terkait kemampuan berhitung adalah dengan menggunakan jarijari tangan, belum menggunakan media lain. Alasan penggunaan jari-jari tangan adalah lebih simpel dan tidak mengeluarkan biaya. Selain itu kegiatan pembelajaran berhitung selalu menggunakan LKS setiap selesai menjelaskan materi berhitung. Hal ini menjadikan siswa bosan dan kurang bersemangat.

Dijelaskan dalam teori yang diungkapkan oleh Ahmad Susanto dalam buku perkembangan anak usia dini tentang tahapan dalam berhitung dijelaskan bahwa kegiatan atau suasana di dalam kelas yang tidak membosankan menjadikan suasana pada proses belajar mengajar asyik dan nyaman untuk anak, dan didukung dengan penggunaan metode pembelajaran yang bervariasi.

Dari penjelasan diatas, dapat disimpulkan bahwa kegiatan berhitung pada kelompok B1 TK Muslimat Wonocolo Surabaya kurang sesuai dengan tahapan berhitung anak, yaitu pada tahap pengertian. Karena kurang memanfaatkan benda-benda nyata yang ada disekitanya. Hal ini yang menjadikan siswa kurang maksimal dalam belajar berhitung.

Mengembangkan kemampuan berhitung pada anak usia dini lebih mudah jika menggunakan media yang menarik dan membuat siswa bersemnagat yang memudahkan siswa dalam memahami atau menguasai suatu materi pembelajaran. Media merupakan suatu alat yang digunakan sebagai perantara atau pengantar yang membawa informasi pelajaran yang bertujuan memudahkan untuk mencapai tujuan pembelajaran. Oleh karena itu, media sangat diperlukan dalam kegiatan pembelajaran. Akan tetapi, hal ini berbeda pada proses pembelajaran yang dilakukan di TK Muslimat Wonocolo khususnya kelompok B1 yang mengatakan bahwa kurang maksimal bila menggunakan media, dulunya guru di sini mengajar dengan menggunakan media, karena banyak waktu yang 
dibutuhkan dan pengkondisian kelas yang kurang maksimal, sehingga guru di sini menggunakan jari sebagai alat berhitung.

Dari penjelasan diatas, dapat diambil kesimpulan bahwa aktivitas pembelajaran kurang sesuai dengan teori Arief S Sadiman dalam buku media pendidikan yang menjelaskan bahwa, media merupakan seperangkat alat yang digunakan oleh pendidikan dalam untuk memperoleh informasi atau pengetahuan.

Berbagai macam media pembelajaran dapat digunakan untuk mengembangkan kemampuan berhitung, salah satunya media corong berhitung. Media corong berhitung adalah salah satu jenis media yang konkret atau nyata, yang dapat dipegang langsung oleh siswa. Media corong berhitung bertujuan untuk memudahkan dalam menguasai kemampuan berhitung penjumlahan dan pengurangan.

Pada dasarnya anak usia dini lebih mudah untuk mengerjakan sesuatu atau memahami sesuatu dengan menggunakan benda yang konkret atau nyata. Selain media corong berhitung merupakan benda yang konkret atau nyata, media corong berhitung juga mempunyai warna. Tujuan warna dalam corong berhitung adalah untuk pengenalan variasi warna saja, tidak ada tujuan tertentu. Hal tersebut dibuktikan dengan jawaban siswa saat guru bertanya ketika sedang menggunakan media corong berhitung, dan dilihat aktivitas siswa yang asyik menggunakan media corong berhitung untuk melakukan penjumlahan dan pengurangan.

Penggunaan media corong berhitung memiliki banyak manfaat, disamping siswa bersemangat dalam belajar, media corong berhitung juga mampu melatih siswa dalam motorik kasar yang dilakukan dengan cara lomba estafet. Selain itu manfaat untuk guru yaitu menjadikan siswa lebih bersemangat, memudahkan peserta didik dalam memahami pembelajaran berhitung, dan membuat siswa tertarik karena bentuknya unik seperti corong minyak. Selain itu, dalam penggunaan berkelompok media corong berhitung juga mampu memberikan interaksi dalam pengerjaan soal yang berkelompok untuk bekerja sama.

Penggunaan media corong berhitung dalam penelitian tingdakan kelas ini dapat meningkatkan kemampuan berhitung penjumlahan dan pengurangan pada siswa kelompok B1 TK Muslimat Wonocolo, dibuktikan dengan cara penggunaan dan kegiatan yang dilakuakn di setiap siklus berbeda-beda dengan tujuan agar siswa tidak merasa bosan saat mengikuti pembelajaran. Selain itu, metode yang digunakan pada setiap siklus juga berbeda, yang tidak menjadikan siswa bosan saat berada di dalam kelas.

Hal ini dibuktikan dengan siswa yang mulai tertarik dengan menggunakan media corong yang berwarna kemudian dilakukan secara kuis dalam artian setiap kelompok akan bersaing untuk mendapatkan banyak poin. Disamping itu, media corong berhitung terdapat kartu soal yang akan dilakukan untuk mengerjakan soal yang ada.

Penggunaan media corong berhitung mampu membuat siswa asyik dan senang, hal ini dibuktikan pula dengan antusias siswa dalam mencari kartu soal yang digunakan untuk mengerjakan corong berhitung. Sebagaimana pendapat yang dijelaskan oleh Badruz Zaman dalam Buku Media dan Sumber Belajar TK mengatakan bahwa terdapat manfaat dalam penggunaan media, salah satunya yaitu memudahkan anak untuk memahami benda yang masih abstrak, karena dengan penggunaan media corong berhitung di sini, kartu soal dengan media corong berhitung berfungsi untuk perantara yang memudahkan soal yang ada pada kartu soal misal $3+4$, jadi konsep abstrak di sini adalah $3+4$, dapat dimudahkan dengan adanya 3 corong dan 4 corong, kemudian dihitung jumlah semua corong yang ada. 
Selain dengan adanya manfaat media memudahkan anak untuk memahami benda yang abstrak, media corong berhitung juga sesuai dengan syarat dipilihnya corong berhitung sebagai media pemeblajaran anak usia dini sebagaimana dijelaskan dalam teori pemilihan media anak usia dini dalam buku Media dan Sumber Belajar TK oleh Badruz Zaman, yaitu media pembelajaran dipilih sesuai dengan tujuan dan karakteristik perkembangan anak usia dini. Hal ini dibuktikan dengan corong berhitung yang memiliki tujuan utama memudahkan siswa dalam memahami konsep berhitung penjumlahan dan pengurangan.

Penggunaan media corong berhitung pada setiap siklus berbeda-beda, siklus I adalah tanpa menggunakan tempat lubang sedangkan pada siklus II menggunakan II lubang. Selain itu materi pembelajaran pada setiap hari bergantian misal hari pertama penjumlahan, hari kedua pengurangan, dan seterusnya.

Pada indikator penjumlahan ARC, SAP, AOF, JNW, MIF, MKH, MAA, MCW, FAR, FMA, FGA, MKGA, TAA, RA, AWI, NAK, AJI, dan ZR sudah mampu tuntas dalam proses belajar dengan persentase ketuntasan $90 \%$ atau 18 siswa sedangkan 2 siswa masih perlu bimbingan dan latihan. Sebaliknya, ARC, SAP, AOF, JNW, MIF, MKH, MAA, MCW, FAR, TAA, RA, AWI, NAK, AJI, dan ZR, CRM sudah mampu melakukan menyebutkan hasil pengurangan dengan tuntas atau dengan persentase $80 \%$ atau sebanyak 16 ssiwa sedangkan sisanya $20 \%$ atau 4 siswa masih perlu latihan dan bimbingan.

Jadi, dapat disimpulkan bahwa peningkatan kemampuan berhitung dilihat dari indikator setiap siklus yang mengalami peningkatan. Peningkatan tersebut antara lain sebagai berikut:

1. Hasil pra siklus menunjukkan bahwa pada indikator menyebutkan hasil penjumlahan mencapai persentase sebesar $20 \%$ dan pada indikator menyebutkan hasil pengurangan sebesar $15 \%$.

2. Hasil siklus I menunjukkan bah pada indikator menyebutkan hasil penjumlahan mencapai persentase sebesar $55 \%$ pada indikator menyebutkan hasil pengurangan sebesar $35 \%$

3. Hasil siklus II menunjukkan bah pada indikator menyebutkan hasil penjumlahan mencapai persentase sebesar $90 \%$ pada indikator menyebutkan hasil pengurangan sebesar $75 \%$.

\section{SIMPULAN DAN SARAN} berikut:

Berdasarkan pada hasil analisis penelitian, maka dapat diambil kesimpulan sebagai

1. Penggunaan media corong berhitung pada siklus I dengan membagi siswa menjadi 3 kelompok, setiap kelompok akan memperoleh media corong berhitung. Berbeda dengan siklus II siswa dibagi menjadi 2 kelompok. Penggunaan corong berhitung pada siklus I tanpa menggunakan lubang tempat corong, sedangkan pada siklus II menggunakan lubang tempat corong. Perbedaan penggunaan media corong berhitung menunjukkan bahwa siswa dapat melakukan kegiatan berhitung penjumlahan dengan cara yang berbeda baik dengan berkelompok maupun individu, sehingga dalam hal ini media corong berhitung mampu meningkatkan kemampuan berhitung siswa.

2. Terdapat peningkatan kemampuan berhitung 1-20 pada siswa kelompok B TK Muslimat Wonocolo Surabaya dengan menggunakan media corong berhitung dengan tingkat ketuntasan belajar siswa pada siklus I sebesar 70\% (14 siswa) untuk indikator 
penjumlahan dan 55\% (12 siswa) untuk indikator pengurangan. Sehingga dapat dikatagorikan pada siklus I masih kurang dengan rata-rata indikator penjumlahan 2,95 dan rata-rata indikator pengurangan 2,7. Berbeda pada siklus II yang terjadi peningkatan dengan perolehan prosentase ketuntasan belajar siswa 90\% (18 siswa) untuk indikator penjumlahan dan $75 \%$ (16 siswa) untuk indikator pengurangan. Sedangkan nilai 3,2 pada indikator penjumlahan dan nilai 3 pada indikator pengurangan.

\section{AKNOWLEDGMENT}

Peneleitian ini di dukung oleh KB/TK Dian Ceria Surabaya dan UIN Sunan Ampel Surabaya.

\section{DAFTAR RUJUKAN}

Arikunto, S. (2006). Prosedur Penelitian Suatu Pendekatan Praktik. Jakarta: Rineka Cipta.

Latif, M. (2013). Orientasi Baru Pendidikan Anak Usia Dini. Jakarta: Prenada Media Group.

Sadiman, A. S. (2006). Media Pendidikan. Jakarta: Rajawali Press.

Sujiono, \& Yuliani. (2004). Metode Pengembangan Kognitif. Jakarta: Universitas Terbuka.

Susanto, A. (2011). Perkembangan Anak Usia Dini. Jakarta: Kencana Prenada Media Group.

Uno, H. B. (2012). Menjadi Peneliti PTK Yang Profesional. Jakarta: Bumi Aksara.

\section{AUTHOR}

Fajar Karuniawati, Merupakan Guru di KB/TK Dian Ceria Surabaya dan Alumni Program Studi Pendidikan Islam Anak Usia Dini Universitas Islam Negeri Sunan Ampel Surabaya

Mukhoiyaroh, Merupakan Dosen UIN Sunan Ampel Surabaya pada Program Studi Pendidikan Islam Anak Usia Dini dan akatif menulis diberbagai jurnal ilmiah 